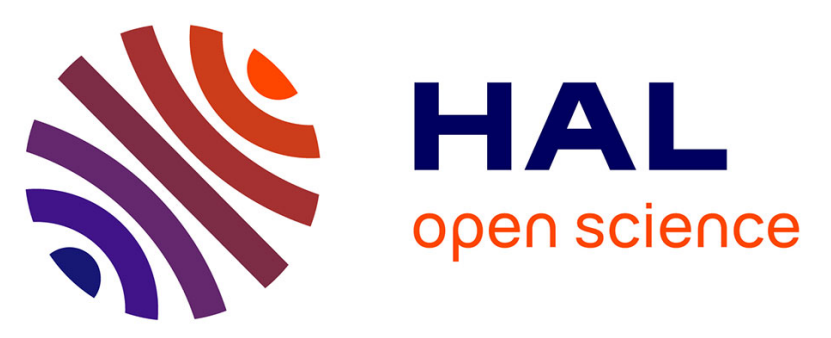

\title{
Water exchange, mixing and transient storage between a saturated karstic conduit and the surrounding aquifer: groundwater flow modeling and inputs from stable water isotopes
}

Stéphane Binet, Emmanuelle Joigneaux, Hélène Pauwels, Patrick Albéric, Christine Fléhoc, Ary Bruand

\section{To cite this version:}

Stéphane Binet, Emmanuelle Joigneaux, Hélène Pauwels, Patrick Albéric, Christine Fléhoc, et al.. Water exchange, mixing and transient storage between a saturated karstic conduit and the surrounding aquifer: groundwater flow modeling and inputs from stable water isotopes. Journal of Hydrology, 2017, 544, pp.278-289. 10.1016/j.jhydrol.2016.11.042 . insu-01402456

\section{HAL Id: insu-01402456 \\ https://hal-insu.archives-ouvertes.fr/insu-01402456}

Submitted on 24 Nov 2016

HAL is a multi-disciplinary open access archive for the deposit and dissemination of scientific research documents, whether they are published or not. The documents may come from teaching and research institutions in France or abroad, or from public or private research centers.
L'archive ouverte pluridisciplinaire HAL, est destinée au dépôt et à la diffusion de documents scientifiques de niveau recherche, publiés ou non, émanant des établissements d'enseignement et de recherche français ou étrangers, des laboratoires publics ou privés.

\section{(ㅇ)(1) $\$$}

Distributed under a Creative Commons Attribution - NonCommercial - NoDerivatives $\mid 4.0$ 


\section{Accepted Manuscript}

Research papers

Water exchange, mixing and transient storage between a saturated karstic conduit and the surrounding aquifer: groundwater flow modeling and inputs from stable water isotopes

S. Binet, E. Joigneaux, H. Pauwels, P. Albéric, Ch. Fléhoc, A. Bruand

PII: S0022-1694(16)30748-X

DOI: http://dx.doi.org/10.1016/j.jhydrol.2016.11.042

Reference: $\quad$ HYDROL 21656

To appear in: $\quad$ Journal of Hydrology

Received Date: $\quad 4$ November 2016

Accepted Date: $\quad 21$ November 2016

Please cite this article as: Binet, S., Joigneaux, E., Pauwels, H., Albéric, P., Fléhoc, Ch., Bruand, A., Water exchange, mixing and transient storage between a saturated karstic conduit and the surrounding aquifer: groundwater flow modeling and inputs from stable water isotopes, Journal of Hydrology (2016), doi: http://dx.doi.org/10.1016/ j.jhydrol.2016.11.042

This is a PDF file of an unedited manuscript that has been accepted for publication. As a service to our customers we are providing this early version of the manuscript. The manuscript will undergo copyediting, typesetting, and review of the resulting proof before it is published in its final form. Please note that during the production process errors may be discovered which could affect the content, and all legal disclaimers that apply to the journal pertain. 


\title{
Water exchange, mixing and transient storage between a
}

\section{saturated karstic conduit and the surrounding aquifer:} groundwater flow modeling and inputs from stable water isotopes

\author{
S. Binet ${ }^{1,3}$, E. Joigneaux ${ }^{1,2}$, H. Pauwels ${ }^{2}$, P. Albéric ${ }^{1}$, Ch. Fléhoc ${ }^{2}$, A. Bruand ${ }^{1}$ \\ Corresponding author: stephane.binet@univ-orleans.fr \\ ${ }^{1}$ Université d'Orléans, CNRS/INSU, BRGM, ISTO, UMR 7327, 45071, Orléans, France \\ ${ }^{2}$ BRGM, Bureau de Recherches Géologiques et Minières, 45000, Orléans, France \\ ${ }^{3}$ Université de Toulouse, CNRS, INP, UPS, EcoLab UMR 5245; ENSAT, Avenue de l'Agrobiopole, 31326 Castanet \\ Tolosan, France
}

\begin{abstract}
Water exchanges between a karstic conduit and the surrounding aquifer are driven by hydraulic head gradient at the interface between these two domains. The case-study presented in this paper investigates the impact of the geometry and interface conditions around a conduit on the spatial distribution of these exchanges. Isotopic $\left(\delta^{18} \mathrm{O}\right.$ and $\left.\delta \mathrm{D}\right)$, discharge and water head measurements were conducted at the resurgences of a karst system with a strong allogenic recharge component (Val d'Orléans, France), to estimate the amounts of water exchanged and the mixings between a saturated karstic conduit and the surrounding aquifer. The spatiotemporal variability of the observed exchanges was explored using a 2D coupled continuum-conduit flow model under saturated conditions (Feflow ${ }^{\circledR}$ ).
\end{abstract}

The inputs from the water heads and stable water isotopes in the groundwater flow model suggest that the amounts of water flowing from the aquifer are significant if the conduit flow discharges are less than the conduit flow capacity. This condition creates a spatial distribution of exchanges from upstream where the aquifer feeds the conduit (recharge area) to downstream where the conduit reaches its maximum discharge 
capacity and can feed the aquifer (discharge area). In the intermediate transport zone no exchange between the two domains takes place that brings a new criterion to delineate the vulnerable zones to surface water.

On average, $4 \%$ of the water comes from the local recharge, $80 \%$ is recent river water and $16 \%$ is old river water. During the November 2008 flood, both isotopic signatures and model suggest that exchanges fluctuate around this steady state, limited when the river water level increases and intensified when the river water level decreases. The existence of old water from the river suggests a transient storage at the aquifer/conduit interface that can be considered as an underground hyporheic zone.

Key words: karst hydrology; stable isotopes; water exchanges; saturated conduit; coupled flow model

\section{Highlights:}

Water exchanges between karstic conduit and aquifer are driven by pressure gradient

Isotopic signature determination and water head measurements were conducted on a karstic aquifer

Exchanges from aquifer water to conduit take place even in pseudo-steady state conditions

The model evidences steady-state exchanges evolving from recharge to discharge areas

With floods, these exchanges fluctuate around the equilibrium and create an underground hyporheic zone 


\section{Introduction: Water exchanges between a karst conduit and the surrounding aquifer}

Water from karstic aquifers is largely used for water supply. In these systems the quantity and quality of outflowing water are highly variable, changing with time following the climatic conditions on the watershed (White, 1999). To help water supply managers, it is fundamental to understand the mechanisms that drive these temporal changes in water quality.

The main known reason for these water quality changes is the huge range of water velocities observed in karst systems. The water flows in three types of porosity: inter-granular porosity within the rock matrix, small aperture fracture porosity, and large cavernous conduit porosity (White, 1999). The matrix porosity and the small fracture porosity around the conduit can be subsumed under the term of aquifer porosity. If the conduits are connected to the surface, the system will be highly vulnerable to the River water dynamics, Intensifying the surface water-groundwater interactions (Sophocleous, 2002)

As these porosities are connected, water can flow from one to the other, causing exchanges or pulses of water that affect the quality of water at the outlet of the karst system. In the literature, existing approaches are conducted at the global scale (Grasso et al., 2003; Butscher 2008; Hartmann et al., 2013) with varying degrees of process representation of the matrix / conduit exchanges. These exchanges are explained hydrodynamically by time changes in water pressure in the conduit that create pressure and mass transfer to/from the aquifer. Bailly-Comte et al. (2010) used mathematical models of karst resurgence recession to show that karst resurgence hydrographs can be interpreted according to pressure transfer between two distinct porosities within the aquifer, conduit and aquifer porosity, which induce two distinct responses at the resurgence. Water exchanges between conduits and aquifer porosity are governed by hydraulic head differences between conduits and matrix, head gradients within conduits, and the permeability difference between conduits and the aquifer (Kovács et al., 2005). If the hydraulic head changes over time are the only driver, it follows that the exchanges must take place under saturated conditions and that the intensity of the exchanges decreases to zero when the system tends to a steady state pressure condition (Bailly-Comte et al., 2010). The water exchange is considered as a transient process. 
The use of stable water isotopes has enriched groundwater conceptual models and has evidenced the physical phenomena taking place in karst systems, such as the differentiation of the catchment areas of the main springs (Andreo et al., 2004), the importance of the recharge elevation gradient (Binet et al., 2006), or the existence of water storage in the epikarstic zone (Lee and Krothe, 2001; Perrin et al., 2003). In their examination of water mixing deduced by water chemistry at the spring, Charmoille et al. (2009) observed that the regional hydraulic gradient and the mixing of water estimated by hydrochemistry could differ, suggesting dynamic local flows in the opposite direction to the regional hydraulic gradient. This suggests that the amount of water exchanged, estimated at the regional scale, may differ from the amount of water mixed between the two kinds of porosities. The use of stable water isotopes or water chemistry in hydrological studies improves the conceptual models of groundwater surface water interactions (Charlier et al. 2010, Doctor et al., 2006; Marfia et al., 2004), making it possible to estimate the relative proportions of the conduit, intermediate, and diffuse flow components (Long and Putnam, 2004). More generally, mixing models from hydrochemistry analysis suggest that in these karst systems $75 \%$ of the water can come from the aquifer (Martin et al., 2003). These mixings take place throughout the year and are significant even if the system tends to a pseudo hydrodynamic steady state in low water periods.

Thus, if the exchanges are driven by pressure transfer, which local conditions (geometric or intrinsic to the karst properties) could induce a steady state pressure disequilibrium between a conduit and the aquifer?

Analysis of the driving mechanisms of water exchanges using coupled models (groundwater flow and transport) is rarely carried out in karst systems because it is very difficult to make the correct assumptions to describe their complexity. This approach is only possible with models that have a high degree of process representation and a high spatial resolution. However, in recent years, the coupled continuum-conduit flow model has enabled the identification of mechanisms that control karst flow. Jeannin (2001) demonstrated the feasibility of using this kind of model to describe actual karst systems. Reimann et al. (2011) provided theoretical evidence of the significance of turbulent flows in the conduit on the exchanges between conduits and the aquifer, and introduced the notion of conduit flow capacity. Depending on the amount of water collected by the conduit compared to its overall flow capacity, a hydraulic gradient at the interface between the conduit and matrix can be determined and will drive the direction and the intensity of the exchanges. 
The divergence between exchanges and mixing led the above-mentioned authors to consider this interface as a hyporheic zone, defined as an area where water infiltrates from the conduit into the aquifer and returns to the conduit after relatively short pathways. The hyporheic zone was first evidenced using water isotopes between Rivers and Alluvium (Mengis et al., 1999). This raises the possibility of transient storage in the aquifer (Gooseff et al. 2003), showing the existence of water with residence times bounded between conduit and aquifer residence times. The existence of this zone was evidenced by modelling (Cardenas et al., 2008) and by a laboratory analog study (Wu and Hunkeler, 2013) but little evidence from a saturated karstic conduit itself has yet been provided.

To study the conditions controlling the exchanges between a conduit and the aquifer, and their spatial significance and relative variability from recharge to discharge areas, we observed a karstic system connected to a sinking river. This paper describes the water exchanges observed in an allogenic karst, the Val d'Orléans aquifer, deduced from stable water isotope signatures and a coupled continuum-conduit flow model calibrated from water head measurements.

In the proposed model, particular attention was paid to the spatial variability of these exchanges, from recharge point to discharge area. The role of the conduit interfaces, pressure transfer and karst geometry on the exchanged water was explored by validating groundwater model with stable water isotopes. Analysis of the November 2008 flood event evidenced the existence of transient storage in this karst system.

\section{Study area: hydrogeology}

The Val d'Orléans is a vast depression in the Loire River main flow, $37 \mathrm{~km}$ long and from 4 to $7 \mathrm{~km}$ wide (Fig.1).

The karst aquifer is hosted within a carbonate lacustrine deposit called the Beauce limestone with a high porosity overlain by the Quaternary alluvia of the Loire River. In some places, a clay layer is interbedded, creating a confined area in the limestones. This geological setting creates a multi-layered aquifer system with significant flux between the alluvia and the limestones (Lepiller, 2006) The Loire River feeds more than $80 \%$ of the water hosted in the carbonate karst aquifer $\left(11.5 \mathrm{~m}^{3} / \mathrm{s}\right.$ during low water periods) (Martin et al., 2003). The groundwater flows from the city of Jargeau where the Loire River sinks providing significant recharge to the groundwater system. Water outflows towards several resurgences of the Loiret River (e.g. the Bouillon) 
through the karst networks (Fig. 1) (Lepiller, 2006). The Bouillon is the main resurgence of the river water infiltrated from the Loire River (from 0.1 to $5 \mathrm{~m}^{3} / \mathrm{s}$ ). The complexity of the system is highlighted by backflooding phenomena (Albéric, 2004), whose frequency of occurrence varies with time (Joigneaux et al., 2011). Backflooding suggests that surface water and groundwater heads are close to the equilibrium, and the direction of the hydraulic gradient between surface and groundwater can be inversed.

Conduit flows of the Val d'Orléans karst system were characterized with 10 dye tracer tests conducted between the recharge points S1 or S2 and the outlet resurgences (Fig.1). Using a straight line distance between input and output points, the flow velocity was found to range between 0.030 to $0.045 \mathrm{~m} / \mathrm{s}$ for hydraulic gradients between $0.13 \%$ o to $0.32 \%$ inside the conduit respectively. The average of the 10 tests gave a velocity of about $0.037 \mathrm{~m} / \mathrm{s}$ for a hydraulic gradient of about $0.2 \%$ (Joodi et al., 2010).

The flow converges from S1 and S2 towards the Bouillon resurgence and the average water residence time is about 100 hours and 45 hours respectively, suggesting an average residence time of the water in the conduit of about $89 \mathrm{~h}$ (about 3.5 days). Downstream tracers diverge as evidenced by the number of resurgence points observed along the Loire River.

The mixing between local aquifer and regional (Loire) flows was documented using hydrochemical analysis (Le Borgne et al., 2005). The water balance showed that $15 \%$ of the water flows from the aquifer (Gutierrez and Binet 2010). Based on chloride mass balance, Albéric and Lepiller (1998) estimated no mixing and Le Borgne et al. (2006) proposed a value of $<4 \%$ using nitrates in waters. This paper will try to explain the apparent contradiction between these mixing calculation values and the water balance by testing the hypothesis of transient storage around the conduit as a possible explanation.

\section{Methodology}

Stable water isotopes sampling and analysis

Rain water, river water and groundwater samples were collected for the analysis of stable water isotope. Monthly rain water cumulative samples were collected from March 1996 to the present (Millot et al., 2010) at the Orléans station of the French monitoring network, which is part of the IAEA/WMO Global Network for Isotopes in Precipitation 
Loire River samples were collected close to Jargeau at the recharge point of the karstic aquifer. The river water level measurements were recorded at the S1 station used for water quality monitoring. Karstic conduit samples were collected from the Bouillon spring, one of the main resurgences (Fig. 1). The sampling campaigns focused on two periods: i) a low water level period from $19^{\text {th }}$ August 2008 to 2 September 2008 with the collection of 6 Loire samples and 6 resurgence samples, and ii) the flood period from the $5^{\text {th }}$ to $14^{\text {th }}$ of November 2008 that recorded a $1.9 \mathrm{~m}$ increase in the water level of the Loire River and a significant increase in the discharge rate of the resurgences. Thirteen Loire samples and 18 resurgence samples were collected during this event. As the tracer results showed a residence time of 3.5 days (Joodi et al. 2010) the sampling procedure during the two focus periods was designed with a time interval of 3.5 days between the Loire and the resurgence sampling.

Twelve additional samples were collected in the Loire River and the Bouillon resurgence between March and September 2009 and three samples were collected in August 2008 from the Saint Nicolas resurgence located 8 $\mathrm{km}$ downstream of the Bouillon.

The F1, F2, and F3 boreholes located within the Val d'Orléans along the karstic flow line (Fig. 1) between the sinkholes and the resurgences were sampled in August 2008 in order to identify the isotope water signature in the aquifer. Collection of water in boreholes was not possible in November, as the boreholes are only operated during the irrigation season.

The stable isotopes ${ }^{2} \mathrm{H}$ and ${ }^{18} \mathrm{O}$ (deuterium $\mathrm{D}$, and oxygen O) were measured using a Finnigan MAT 252 mass spectrometer with a precision of $0.1 \%$ vs. SMOW (Standard Mean Ocean Water) for $\delta^{18} \mathrm{O}$ and of $0.8 \%$ for $\delta^{2} \mathrm{H}$. Isotopic compositions are reported in the usual $\delta$-scale in \%o with reference to V-SMOW (Vienna Standard Mean Ocean Water). The $\mathrm{D}$ and $\mathrm{O}$ isotopic ratios, reported in per mil deviations from the international SMOW standard, were analyzed using a Finnigan MAT 252 mass spectrometer. The average precision, based on multiple analyses of various samples and laboratory standards, was $\pm 0.1 \%$ ofor $\delta^{18} \mathrm{O}$ and $\pm 0.8 \%$ for $\delta^{2} \mathrm{H}$ (Négrel et al., 2003).

\section{Groundwater flow model}

The amount of water exchanged between a saturated conduit and the aquifer can be estimated using groundwater flow calculations with two domains: the conduit $(\mathrm{C})$ and the surrounding aquifer $(\mathrm{A})$. Following 
Jeannin (2001) and Reimann et al. (2011), the conduit discharge Qc $\left(\mathrm{m}^{3} / \mathrm{s}\right)$ for turbulent conditions can be described using a 1D Manning-Strickler law (equation 1):

$Q c=-A_{c} f r^{2 / 3} \sqrt{d h / d x}$ (Equation 1$)$

where $d h / d x$ is the head loss in the conduit at the $x$ location $(/), r$ is the hydraulic radius of the conduit (m), $f$ is the friction coefficient $\left(\mathrm{m}^{1 / 3} \mathrm{~s}^{-1}\right)$ and $\mathrm{A}_{\mathrm{c}}$ the cross sectional area of the conduit $\left(\mathrm{m}^{2}\right)$. The conduit is considered to be fully saturated, and the radius is considered to be constant in space (equivalent radius).

The flows in the aquifer are described using a Darcy law generalized with the continuity equation for a horizontal phreatic two-dimensional aquifer:

Ss $\frac{d h}{d t}-\operatorname{div}(K s \operatorname{grad} h)=R \psi($ Equation 2)

where $\mathrm{Ks}$ is the hydraulic conductivity of the aquifer $(\mathrm{m} / \mathrm{s})$, Ss the storage coefficient $(/)$ and $\mathrm{R}$ the vertical recharge in the cell $(\mathrm{m} / \mathrm{s})$.

\section{Model structure}

The spatio-temporal variability of the observed exchanges was explored using a 2D coupled continuum-conduit flow model under saturated conditions (Feflow ${ }^{\circledR}$ ). The Val d'Orléans aquifer was modelled in 2 dimensions as a $4 \mathrm{~km}$ wide $* 20 \mathrm{~km}$ long square, in which a single conduit is immersed in the center as a discrete feature were Manning Strickler law is applied (Fig. 2). The two domains were discretized using a triangle mesh method (Shewchuk, 1996). The mesh size ranged from $1 \mathrm{~m}^{2}$ in the conduit to $100 \mathrm{~m}^{2}$ in the aquifer, close to the no-flow boundary, with 22800 nodes. At the interface between the conduit and the aquifer, we assumed that the hydraulic heads in the conduit and in the aquifer were equal.

\section{Boundary conditions and justifications}

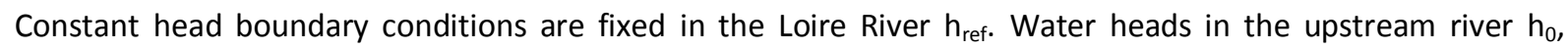
downstream river $h_{1}$ and at the Bouillon resurgence $h_{R}$ are fixed respectively at 99, 87 and 90.3 meters above sea level for the steady state calculations. The flood were modelled increasing upstream river head from 99 to 101.6 meter in 5 days, and then decreasing back in 7 days, according to the observations realized during the November 2008 flood at the Jargeau station. 
The flow rates at the river water-groundwater interfaces were calculated from the transfer rate $\phi\left(\mathrm{m}^{2} / \mathrm{s}\right)$, and the difference between $h_{\text {ref }}$ the river head and $h$ the groundwater head:

$Q=\Phi\left(h_{\text {ref }}-h\right)$ (equation 3)

$Q_{c 0}\left(\mathrm{~m}^{3} / \mathrm{s}\right)$ is the flow rate inflowing from the River into the conduit. $Q_{c 1}\left(\mathrm{~m}^{3} / \mathrm{s}\right)$ is the flow rate outflowing from the conduit toward the river. $Q_{A 0}\left(\mathrm{~m}^{3} / \mathrm{s}\right)$ is the flow rate inflowing from the River into the aquifer. $Q_{A 1}\left(m^{3} / s\right)$ is the flow rate outflowing from the aquifer toward the river. A Neumann boundary conditions are used here to accommodate the fact that for a given head in the river, the head below the river is founded to change between the conduit and the aquifer domains.

The overflow at the Bouillon resurgence is noted $Q_{R}$, and is calculated with equation 3 using $h_{R}=90.3 \mathrm{~m}$. The flow rate in the conduit below the resurgence is noted $Q_{C R}$.

\section{Water exchange calculation}

This paper investigates the exchanges between the aquifer and the conduit. The ratio of water flowing from the aquifer into the conduit \%A between the upstream boundary condition and the resurgence was calculated as follows:

$\% \mathrm{~A}=\left(\mathrm{Q}_{\mathrm{CR}}-\mathrm{Q}_{\mathrm{C} 0}\right) / \mathrm{Q}_{\mathrm{CR}} \quad($ Equation 4$)$

If $\% \mathrm{~A}<0$, the conduit recharges the aquifer, while if $\% \mathrm{~A}>0$, the aquifer feeds the conduit. \%A was calculated from each cross sectional area of the conduit.

Based on equation 4, Reimann et al. (2011) and Bailly-Comte et al. (2010) introduced the notion of conduit capacity $\mathrm{Q}_{\mathrm{cm}}$. This is the maximum discharge that the conduit can evacuate for a given hydraulic gradient. Here the maximum conduit capacity $\mathrm{Q}_{\mathrm{cm}}$ is described as:

$Q_{c m}=A c f r^{2 / 3} \frac{\left(\mathrm{h}_{0}-\mathrm{h}_{1}\right)}{\mathrm{L}}$ (Equation 5)

For given conduit properties and a given hydraulic gradient, the discharge $\mathrm{Q}_{\mathrm{cm}}$ represents the maximum discharge flowing into the conduit, for a given geometry. In order to characterize the drainage state of the conduit, the dimensionless discharge ratio \%Q was defined as the ratio between the discharge in the conduit $\left(Q_{c}\right)$ and the maximum discharge capacity $\left(Q_{c m}\right)$ : 
$\% Q=Q_{c} / Q_{c m}$ (equation 6)

$\% \mathrm{Q}$ characterizes the amount of water flowing in the conduit with respect to the theoretical discharge in the same conduit without exchanges. $\% \mathrm{Q}<1$ means that the conduit could drain more water. $\% \mathrm{Q}=1$ means that the discharge in the conduit is maximum, i.e. the maximum capacity has been reached. $\% \mathrm{Q}>1$ means that the hydraulic head in the conduit is higher than that in the aquifer, so the conduit feeds the aquifer. \%Q includes the geometric properties of the conduit.

\section{Parameter selection and initial conditions}

In this paper, 120 water-head measurements performed in boreholes during the July-September 1966 base flow (Desprez, 1967) in and around the karstic network were used to calibrated the steady-state numerical groundwater flow model results. The boreholes are located in Figure 1, and the dataset was extracted from the French geological survey (BRGM) Database (www.infoterre.fr). To exploit these observations, the measurements from the observation wells were projected on a $[0,1]$ cross section located in Fig. 1 , crossing the aquifer from the recharge area (0) to the discharge area (1). Projected on the cross section, the water heads observed in the conduit and the aquifer can be compared to determine the direction and the intensity of the exchanges between conduit and aquifer at the point $x$ of the cross section. The annual difference between these two levels is $1 \mathrm{~m}$.

The recharge infiltrated from the surface to the karst system (R) is about $5 \mathrm{~mm} / \mathrm{yr}$ for a watershed of about 284 $\mathrm{km}^{2}$ (Gutierrez and Binet, 2010). This impact of local recharge on the resurgence water is highlighted by the existence of organic contaminants in resurgence water (Dedewanou et al., 2015). Martin et al. (2003) synthesized the hydrogeological properties of the geological layers.

Pumping tests in the limestone showed a hydraulic conductivity (K) of c. $5 \mathrm{E}-4-30 \mathrm{E}-4 \mathrm{~m} / \mathrm{s}$ and a storage coefficient $(\mathrm{S})$ of about $10^{-3}$, suggesting a confined aquifer system for a $30 \mathrm{~m}$ thickness. The primary porosity of the lake deposit limestone can reach 5\% (Waschkowski, 1973). $\mathrm{K}_{\mathrm{s}}$ was fixed at $25 \mathrm{E}-4 \mathrm{~m} / \mathrm{s}$, the average value of data from pumping tests and transmissivity was calculated assuming an aquifer with a thickness about $30 \mathrm{~m}$.

Conduit properties were derived from 10 tracer tests (Joodi et al. 2010) and explorations by speleologist divers, present a global flow rate of 2 to $10 \mathrm{~m}^{3} / \mathrm{s}$ for cross sectional area of about $10 \mathrm{~m}^{2}$ (Auterives et al., 2014). 
The initial condition for steady state was $h(x, y)=99 m$ and the results of $h(x, y)$ obtained during the steady state were used as the initial conditions of the transient calculation.

\section{Model runs and performances}

The equation-system solver used was SAMG in Feflow (Diersch, 2014), a linear solver for groundwater simulation with a convergence criterion of $<10^{-8}$ for the steady state hydraulic head calculation. To improve repeatability of the results, a second run was carried out with a second convergence criterion on the water budget, $<1.15 \mathrm{E}-5 \mathrm{~m}^{3} / \mathrm{s}$. Transient calculation were performed with a $1 / 4$ hour time step.

Steady state calibration were performed following a step by steps procedure: first, Conduit properties (f, $A_{c}$ ) were estimated to adjust the flow velocity and discharge observed in the conduit by tracer tests (Fig. 5). Then, the transfer rates were estimated during the groundwater model calibration to reach the best fit model defined by a Nash criteria calculated on the groundwater heads in the aquifer.

Validation of the transient hydrological model were performed using a Nash criteria calculated on the discharges observed during the November 2008 flood.

Sensitivity analysis was performed, for steady state conditions, using a One-At-a-Time (OAT) method to test the local sensitivity of the model parameters around the values defined by the best fit model, adapted for the Val d'Orléans context. For each input parameter with an $\mathrm{x}$ best fit value, a range $\Omega$ of the admissible variations was defined. $\sigma$ was considered to be $1 / 4$ of this $\Omega$ range and runs were performed for $x+\sigma$ and $x-\sigma$ values, under steady state conditions (Razavi and Gupta, 2015). The sensitivity of the boundary conditions were tested changing the hydraulic gradient $\mathrm{i}=\left(\mathrm{h}_{\mathrm{A0}}-\mathrm{h}_{\mathrm{A} 1}\right) / \mathrm{L}$. For the hydraulic conductivity and the recharge, the tests were performed on the log of the $\mathrm{x}$ and $\sigma$ values. The conduit properties, $A c . f . r^{2 / 3} \sqrt{d h / d x}$, were grouped in the term $Q_{C}$ and the interface properties $\Phi$ were tested from the discharge values flowing through the interfaces: $Q_{A 0}, Q_{A 1}, Q_{C 0}, Q_{C 1}$ (equation 3). Screening was conducted in the $\Omega$ range in order to identify the influence of the parameter $x$ on the conduit / aquifer exchanges $(A)$. The impact of $x$ on $A$ were evaluated using a percentage difference. The parameters were ranked according to this percentage. (Pianosi et al., 2016).

During the November 2008 flood calculation, the values of $Q_{C 0}, Q_{C M}$ and \%Q where extracted of the model when the water level reach, 97.5, 98.4, 99.1 and 101.6 meter (Table 1). 


\section{Quantification of fluxes using stable isotopes}

\section{Qualitative input}

The difference between isotopic composition at the resurgence and at the Loire 3.5 days earlier is a qualitative indicator of the exchanges between the conduit and the aquifer. If the difference is null, all the resurgence water comes from the Loire River. If the difference increases, this means that the proportion of water from the aquifer increases. This difference can be compared with the proportion of water from the surrounding aquifer (\%A) calculated by the groundwater model.

\section{Quantitative input}

The isotope composition of the resurgence can be compared to the isotope composition of the waters coming from the aquifer and the River using an end-member analysis. They were calculated by applying a mass balance equation:

$\left[\begin{array}{l}\delta D_{\text {resurgence }}=(1-\% A) \delta D_{\text {river }}+\% A D_{\text {aquifer }} \quad \text { (equation 7) } \\ \delta^{18} O_{\text {resurgence }}=(1-\% A) \delta^{18} O_{\text {river }}+\% A^{18} O_{\text {aquifer }}\end{array}\right.$

where $\delta \mathrm{D}_{\text {resurgence }}$ and $\delta^{18} \mathrm{O}_{\text {resurgence }}$ are the isotope compositions of the resurgence at a given time, $\delta \mathrm{D}_{\text {river }}$ and $\delta^{18} \mathrm{O}_{\text {river }}$ are the isotope compositions of the Loire 3.5 days previously. $\delta \mathrm{D}_{\text {aquifer }}$ and $\delta{ }^{18} \mathrm{O}$ aquifer, the isotope compositions of water coming from the aquifer, are unknown and may change with time. Thus it is inadequate to calculate a proportion of water coming from the aquifer directly with isotopic data. To overcome this limitation, in isotope hydrology which assumes that aquifer as an end-member, the methodology chosen in this paper was to use the groundwater model results in the end-member analysis to estimate the proportion of water coming from the aquifer \%A. The relative difference between observed and calculated $\delta \mathrm{D}_{\text {aquifer }}$ and $\delta^{18} \mathrm{O}$ aquifer will provide validation of the proposed $\% \mathrm{~A}$ in the groundwater model. The change of $\delta \mathrm{D}_{\text {aquifer }}$ and $\delta{ }^{18} \mathrm{O}$ aquifer during the flood, compared to seasonal pattern of the isotopes in rain, will provide information about the origin of the aquifer waters. 


\section{Results}

\section{Stable water isotopes for evaluation of water exchanges}

\section{Pseudo-steady-state conditions: summer and winter 2008}

In the Loire River, $\delta \mathrm{D}$ ranged between $-53.3 \%$ and $-48 \%$ during the high water flows from November to May and increased during the low flow period from June to September, between $-43.9 \%$ and $-40.9 \%$. $\delta^{18} \mathrm{O}$ ranged between $-8.1 \%$ and $-7.4 \%$ o during the high flow period and increased to between $-6.8 \%$ and $-5.9 \%$ o during the low flow period (Fig. 3a). At the Bouillon resurgence, distinct signatures were also observed between low and high water level periods respectively: $\delta \mathrm{D}$ ranged from $-51.6 \%$ to $-45.6 \%$ and $\delta^{18} \mathrm{O}$ from $7.8 \%$ to $-7 \%$ during the high flow period, whereas during low flow, less depleted values were recorded with $\delta \mathrm{D}$ ranging from $-46.2 \%$ to $-42.4 \%$ and $\delta^{18} \mathrm{O}$ from $-6.8 \%$ to $-6.2 \%$ (Fig. 3a). All Loire River and resurgence data plot very close to the Local Meteoric Water Line determined from the 1996-2009 Data base and expressed as:

$\delta \mathrm{D}=7.96( \pm 0.07) * \delta^{18} \mathrm{O}+9.6( \pm 0.6) \quad$ (equation 8$)$

The variability in the dataset is also characterized by more depleted values during winter than during summer (Fig. 3a).

During summer 2008, the stable water isotope signature at the Saint Nicolas resurgence $\left(\delta^{18} \mathrm{O}=-6.3 \%\right.$ and $\delta^{2} \mathrm{H}=-42.7 \%$ ) fitted with the composition at the Bouillon resurgence $\left(\delta^{18} \mathrm{O}=-6.3 \%\right.$ and $\delta^{2} \mathrm{H}=-42.7 \%$ ).

At the end of August, after several weeks without rainfall, highlights the deviation of the stable isotope composition during transfer within the karst, with a systematically more depleted composition in the resurgence water $\left(\delta^{18} \mathrm{O}=-6.3 \%\right.$ and $\delta^{2} \mathrm{H}=-42.5 \%$ ) compared to the Loire samples collected 3.5 days previously $\left(\delta^{18} \mathrm{O}=-6.2 \%\right.$ and $\delta^{2} \mathrm{H}=-42 \%$ ) (Fig. 3.b).

The composition of the resurgence is lined up along the mixing line between the Loire and the mean annual isotopic content weighted by the rainfall volume (Fig 3.b). The isotope composition of groundwater collected in the 3 boreholes is close to the local meteoric water line (Fig 3a), and varies along the above-mentioned mixing line with the isotope composition of borehole $n^{\circ} 1\left(\delta^{18} \mathrm{O}=-6.4 \%\right.$ and $\left.\delta^{2} \mathrm{H}=-42.4 \%\right)$ fitted with the signature of the resurgence in the sampling period (August 2008), whereas borehole $n^{\circ} 2$ presents a stable 
water isotope signature $\left(\delta^{18} \mathrm{O}-6.9 \%, \delta^{2} \mathrm{H}=-45.2 \%\right.$ ) that is very close to the mean annual weighted composition of precipitations (Fig. 3a and b).

\section{Stable water isotopes during the November 2008 flood}

Large variations in both $\delta^{18} \mathrm{O}$ and $\delta \mathrm{D}$ were observed in the Loire and the resurgence during the November flood (Figure.4). In the Loire River, the decrease was very rapid for both $\delta^{18} \mathrm{O}$ and $\delta \mathrm{D}$ and concomitant with the river flowrate increase, both isotopes attaining their most negative values with the maximum flowrate. In the resurgence, the decrease was also high but shifted by about 3-4 days compared to the Loire. In Figure 4 , each sample collected in the Loire River 3.5 days previously is compared to the sample collected in the resurgence. As during the low flow period, the isotope signatures show discrepancies, highlighting the occurrence of a significant contribution from the aquifer during the transfer; the resurgence waters appear to be less depleted than Loire river waters. In fact, the isotope signature discrepancy between the Loire River and the resurgence evolved with time (during the event). The water outflowing at the Bouillon resurgence on $7^{\text {th }}$ of November had a water isotope composition very close to that of the water of the Loire River 3.5 days earlier (Fig. 3c). In the same time, the level of the Loire river started to rise to its high level (101.6 m). Thus the contribution from the aquifer during the transfer appears to be negligible. But as soon as the water level decreased, the contribution from the aquifers was observed and the main discrepancy, reaching about $-0.5 \% \circ \delta^{18} \mathrm{O}$ and $-2.1 \%$ for $\delta \mathrm{D}$, was recorded between the water infiltrated from the Loire within the karst on $6^{\text {th }}$ November a.m. and sampled in the resurgence on $9^{\text {th }}$ November p.m.

\section{Groundwater model for evaluation of the water exchanges}

\section{Calibration of the groundwater flow model}

In the conduit, for a given $25 \mathrm{E}-4 \mathrm{~m} / \mathrm{s}$ hydraulic conductivity in the aquifer, the comparison (Fig. 5A) between observed flow velocity and hydraulic gradient from Joodi et al. (2010) and the model results with a friction coefficient ranging between 10 to $30 \mathrm{~m}^{1 / 3} / \mathrm{s}$ suggests that the friction coefficient in the Val d'Orléans is about $13 \mathrm{~m}^{1 / 3} / \mathrm{s}$. This comparison shows that the Manning Strickler law is appropriate to describe the flows in this karstic conduit. By fixing the friction coefficient and the discharge, an equivalent conduit cross sectional area of about $40 \mathrm{~m}^{2}$ (Fig. 5B) was estimated. The criterion to adjust the discharge at the interface of the 
aquifer $Q_{A 0}$ and $Q_{A 1}$ was the observed water heads in aquifer. Fitting was performed using the transfer rate parameter $\Phi$. The best fit was found for $\Phi$ corresponds to a discharge in the conduit $Q_{c 0}$ of about $11 \mathrm{~m}^{3} / \mathrm{s}$ and to a discharge in the aquifer $Q_{A 0}$ of about $1.5 \mathrm{~m}^{3} / \mathrm{s}$. This contrast between the two domains highlights a strong connection between the river and the karstic conduit.

\section{Water exchanges under steady state conditions}

Based on these calibration, Figure 6 shows a cross section of the water heads between Jargeau and the confluence measured during 1966 base flow. The observed water heads are projected on the [0-1] axis (Fig.1) and are represented by triangles. The continuous line corresponds to the modeled water heads in the conduit and the dashed line to the water heads in the aquifer. The Nash criteria is about 0.85 .

Upstream (Fig.6), the water heads in the aquifer were found to be higher than the water head in the conduit, $\% \mathrm{Q}$ is below 1 , the aquifer contributes to feeding the conduit delimiting a recharge zone. Close to the resurgences, the pressure difference between aquifer and conduit is null $(\% Q=1)$; this is a transport zone. Then downstream the water heads in the conduit are higher than the aquifer water head. In this discharge zone, the conduit feeds the aquifer (\%Q >1). In the recharge and discharge zone, the observed values (Fig.6) are bounded by modeled heads in the conduit and in the aquifer, meaning that all the variability of the water head observed in the Val d'Orléans can be explained by conduit / aquifer exchanges. With this configuration, water exchanges between conduit and aquifer are possible even if the calculations were carried out in steady-state conditions.

With these geometric conditions, the maximum discharge in the conduit $\mathrm{Q}_{\mathrm{cm}}$ (Equation 4 ) is about $12.5 \mathrm{~m}^{3} / \mathrm{s}$ if the Loire River level is low (98.4 m).

\section{Applying the groundwater flow model to the November 2008 flood}

For a $10^{-3}$ storage coefficient in the aquifer, combined with a $1.9 \mathrm{~m}$ increase in the water head (with respect to the observed November 2008 Loire River flood) the groundwater model calculates the exchange for transient conditions.

Results, plotted in Figure 4, compare the field discharges measured at the Bouillon resurgence (dots) and the model results with the total discharge and the discharge coming from the aquifer (lines). The 
Nash criteria, calculated on the discharge, is about 0.89 . The model reproduces the blocking of the exchanges during the flood and the strong increase just after the flood. To illustrate these results, water heads calculated around the conduit were extracted from the transient groundwater model in a transversal cross section ( $x=5000 \mathrm{~m}$, Figure 7). The conduit is located at $x=2000 \mathrm{~m}$. On $11 / 04 / 2008$, before the flood, pressure was lower in the conduit, and $16 \%$ of the conduit waters came from the aquifer. The calculated transversal hydraulic gradient was about $30 \mathrm{~cm}$ per $500 \mathrm{~m}$, i.e., $1.4 \%$. From $11 / 04 / 2008$ to $11 / 08 / 2008$, the water head increased in the Loire River. During this pressure increase, the calculated local gradient around the conduit was inverted, and $0 \%$ of the aquifer water reached the conduit and \%Q equal to 1 . When the pressure decreased in the Loire River and in the conduit (November $9^{\text {th }}$ ), the amount of water coming from the conduit was maximum (33\%). This amount of exchange is confirmed by the $3 \%$ transversal hydraulic gradient. The rapid pressure decreases in the conduit after the flood intensified the exchanges.

The dispersion of the \%Q value observed for the Val d'Orléans aquifer suggests that point recharge $\left(Q_{c 0}\right)$ is river head dependent. The \%Q ranging from 0.45 to 1 (Table 1 ) suggests that the conduit discharge is close to its maximum capacity during the flood.

\section{Sensitivity analysis}

Table 2 presents the sensitivity analysis of the model parameters on the percentage of water flowing from the aquifer to the conduit. The table presents the variations of this \%A ratio if the model parameters change about +- the $v$ value. In the best fit model, the \%A is estimated at 0.16 . Results evidence a low effect of the recharge rate, the downstream flow rate at the interface, the hydraulic gradient in the aquifer and the conduit properties on the exchanges between the conduit and the aquifer. The hydraulic conductivity has a significant impact on these exchange with a $\Delta \% \mathrm{~A}=-12 \%$, but less than the upstream interface properties $\left(Q_{A 0}\right)$ that can influence the results up to $\Delta \% \mathrm{~A}=-56.4 \%$. The increase of the discharge input in the conduit $\mathrm{Q}_{\text {co }}$ reduces the exchange that can fall close to 0 . Given our field measurement uncertainties on the hydraulic conductivity and the input discharge, the uncertainty on $\% \mathrm{~A}(\triangle \mathrm{A})$ was estimated to be about $5 \%$. 


\section{Inputs from the stable water isotopes in the groundwater model}

Figure 8 presents $\delta{ }^{18}$ Oversus $\delta D$ during the November 2008 flood in both the Loire and the resurgence, but zooms in on the aquifer domain. It shows the isotope composition of water in the aquifer calculated by applying the mass balance equations (equations 7) where $\% \mathrm{~A}$ is the proportion of water coming directly from the aquifer and calculated by the groundwater flow model (dashed line in Figure 5). The error range was estimated to be about $0.3 \%$ and $2.3 \%$ o for respectively $\delta^{18} \mathrm{O}$ and $\delta \mathrm{D}$. From the $8^{\text {th }}$ to the $13^{\text {th }}$ November, the calculated composition lay between $-6.4 \%$ and $-7.0 \%$ for $\delta^{18} \mathrm{O}$ and between $-43.3 \%$ and $-46.0 \%$ of $\delta \mathrm{D}$, corresponding to the variation in the composition of groundwaters collected in the boreholes. The absolute difference between observed and calculated average isotopic composition in the aquifer is $0.1 \%$, equal to analytic uncertainty.

\section{Discussion:}

Evidence of water exchanges between conduits and the aquifer from the stable water isotopes.

Depleted values during the high flow period compared to the low flow period have already been observed, with clear transitions appearing in May-June and October-November respectively (Négrel et al., 2003). This possibly indicates that the summer water, dominated by groundwater, may originate from precipitations with a more enriched $\delta^{18} \mathrm{O}$ than the winter water, dominated by surface water, which may originate from snowmelt (Grosbois et al., 2000) and depletion can be interpreted as a change in the mixing proportion between "Massif central" and local meteoric waters (Fig.3C). It clearly appears that the stable isotope values of the Bouillon resurgence match with those of the Loire River (Fig.4). During the high flow period, the data ranges were very similar at the two sampling points, but a slight discrepancy appeared during the transition period in May-June and persisted during the low flow period with more depleted values in the resurgence than in the Loire, suggesting the contribution of an additional component (Fig. 3a), coming from the aquifer. Clearly groundwater collected from boreholes and therefore water in the aquifer surrounding the conduits, is also a mixture of the two components: local recharge from the surface (rain) and the recharge of the karst by the Loire river sink. 


\section{Groundwater model parameters and estimation of the water exchanges}

The connection between the Loire River and the Bouillon resurgence is in agreement with the previous identification of the origin of Bouillon resurgence waters (Albéric and Lepiller, 1998). The $13 \mathrm{~m}^{1 / 3} / \mathrm{s}$ value of the friction in the conduit is in accordance with Jeannin (2001) and Jourde et al. (2007) who found respectively 8 and a range between 7 and $22 \mathrm{~m} / 3 / \mathrm{s}$, close to values proposed for natural river bed. Values are relatively different to those of 50 to $35 \mathrm{~m}$ /3/s proposed by Peterson and Wicks (2006) than are close to the values founded for concrete surfaces. The conduit cross sectional area $\left(40 \mathrm{~m}^{2}\right)$ is higher than the observed cross sectional area (close to $10 \mathrm{~m}^{2}$ ), suggesting that the conduit network in the Val d'Orléans aquifer is composed of 3 or 4 parallel main conduits. Lastly, the $14.5 \mathrm{~m}^{3} / \mathrm{s}$ maximum discharge capacity calculated by the model for a river level at Jargeau around $99 \mathrm{~m}$ is close to the maximum $14 \mathrm{~m}^{3} / \mathrm{s}$ outflow estimated using satellite infrared imagery in the Loire River (Lalot et al., 2015). The discharges are coherent with field estimations of the water flow in this conduit (Gutierrez and Binet, 2010).

Water exchanges can take place in steady state conditions from one domain to another. The point recharge $\left(Q_{c 0}\right)$ and point discharge $\left(Q_{c 1}\right)$, compared to the maximum discharge capacity, are the key parameters controlling the exchange between conduit and the aquifer.

Upstream if the conduit capacity is not reached (Fig.6), the conduits drain the aquifer. $Q_{c 0}$ is lower than $Q_{c m}$. This configuration enables the recharge of the drain by the aquifer which induces the isotopic change observed at the resurgences compared to the Loire. Downstream discharge interface properties are the limiting factors of flows in the Orléans karst system. The conduits outflow in the Loire alluvium which reduces the downstream flow velocity $\left(Q_{c 1}\right)$. The conduit cannot be drained freely. The conduit pressure is higher than in the aquifer, and in this case the conduit under pressure feeds the aquifer. This pressure distribution explains the divergent flows observed by the tracer tests and the particular geometry of the divergent karstic conduit observed downstream (Joodi et al., 2010).

The steady state calculations evidence exchanges between the aquifer and the conduit, whose direction and intensity are controlled by the value of the discharge at the limit $\left(Q_{c 0}\right.$ and $\left.Q_{c 1}\right)$ compared to the maximum capacity of the conduit $\left(\mathrm{Q}_{\mathrm{cm}}\right)$. 
If the head in the river is low, $\mathrm{Q}_{\mathrm{co}}$ is lower than $\mathrm{Q}_{\mathrm{cm}}$ and discharge in the conduit is controlled by the interface properties $\mathrm{Q}_{c o}$ (Table 1). During transient evolution, when the river head reaches a threshold, the conduit discharge $Q_{c}$ reaches its maximum capacity, and the point recharge becomes dependent on the maximum conduit capacity. The interface flow rate and the maximum discharge capacity are the two limiting factors for the recharge of the aquifer.

\section{Inputs from the stable water isotopes in the groundwater model}

\section{Steady state water exchanges between conduits and the aquifer}

Most of the year, even if the level of the Loire River does not change, a difference is observed between the isotopic composition in the resurgences and in the Loire River 3.5 days previously (Fig.3). This is in accordance with the groundwater flow model, which estimates $16 \%$ of water from the aquifer in steady state conditions.

The stability of the isotopic composition between the Bouillon and Saint Nicolas resurgences observed in summer 2008 suggests no more recharge from the aquifer to the conduit downstream to the Bouillon resurgence. This is consistent with the transport zone evidenced by the groundwater model (Figure 6).

For the high water level, the average value of $\% \mathrm{Q}$ is close to 1. If $\% \mathrm{Q}$ reaches 1 , the conduit will be under pressure with respect to the aquifer and in this case the conduit can recharge the aquifer, according to Reimann et al. (2011). No exchange is recorded by isotopic measurements. The exchanges may be inverted, from the conduit to the aquifer.

Sensitivity analysis evidences a control of the exchange by the interface properties of the aquifer recharge rather than by the hydraulic conductivity. The same remarks can be made between conduit properties and input discharge in the conduit. This is a local ranking of the model, and the hierarchy between the limiting factors may change for another study area.

\section{Origin of the aquifer waters}

During the November 2008 flood, isotope composition showed the evolution of the exchanges from the aquifers with time, in 3 phases: A) the absence of any exchanges from the aquifer, B) the high exchange during 
abatement of the flood on November $9^{\text {th }}$ and C) a return to an intermediate equilibrium. For these 3 phases, the difference between Loire and resurgence in $\delta^{18} \mathrm{O}$ was respectively $0,0.5$ and $0.25 \%$. This scheme is qualitatively consistent with the $0 \%, 33 \%$ and $16 \%$ of water coming from the aquifer calculated with the groundwater flow model for the same period (Figure 7) and confirms the model's accuracy in terms of water exchange. The groundwater isotope signature evolves from the composition of the resurgence at the end of summer to more depleted values, very close to the mean annual weighted composition of local rainfall. The contribution from local recharge is observable both during the low water level period and the flood and is in agreement with the composition of groundwater collected from boreholes.

This evolution of the isotope signatures coming from the aquifer clearly identifies a change in the origin of the water. On $8^{\text {th }}$ November, at the beginning of the flood, the calculated aquifer endmember was close to the summer rainfall value. Water arriving in the conduit was exchanged recently, at the end of the summer. Then from the $9^{\text {th }}$ to the $13^{\text {th }}$ November, the drainage by the conduit mobilized waters with an isotopic signature closer to that of the annual rainfall. This suggests more distant water coming from the local recharge, correlated with the strong transversal hydraulic gradient. The exchanges observed before the November flood require waters with a summer signature, and the high exchange observed during abatement of the flood may require older waters, with an isotopic signature closer to the yearly endmember.

\section{Underground hyporheic zone}

For low waters, the groundwater flow model validated by isotopic results estimates that the Bouillon resurgence is fed by $16 \%$ of water from the aquifer, which is consistent with the water balance realized by Gutierrez and Binet (2010). Based on mass balance, Albéric and Lepiller (1998) and Le Borgne et al. (2006) proposed aquifer water values of $<4 \%$.

Here with the stable water isotopes we also demonstrate that the groundwaters are mixed, with a significant amount of local rain water and old water from the River. This explains the differences between these results. Compared to the high concentrations observed in local water and boreholes that can reach $500 \mathrm{mg} / \mathrm{L} \mathrm{of}$ nitrates (Le Borgne et al. 2006), It is admissible to consider that the Loire river nitrate and chloride contents remain unchanged during the flooding compared to groundwaters. If the water coming from the aquifer is Loire River water that infiltrated previously and underwent transient storage around the aquifer, then the 
water will have a Loire river chemical content (no mixing was recorded using the mass balance method), but as the water was delayed, its isotopic contents are different due to the seasonality of the signal, providing support for the $16 \%$ estimated by hydraulic calculation. This suggests that resurgence water is a mixing of local rainwater $(<4 \%)$ and Loire river water $(>96 \%)$. The latter can be divided into old Loire river water $(16 \%)$ and recent water (80\%). This mixing is conceptualized in Figure 9.

If we accept the definition of a hyporheic zone given by Cardenas et al. (2008), the results presented here confirm that the aquifer around a conduit can be considered as an underground hyporheic zone, where water infiltrates from the conduit then flows through the aquifer and returns to the conduit after relatively short pathways (Figure 9). This mechanism defines a recharge zone that is highly vulnerable to local recharge and a transport zone that is less exposed to surface vulnerability.

\section{Limitation and uncertainty of the applied methods and modelling}

Two end-members (resurgence and river) were assumed in this interpretation of the aquifer isotopic composition. The existence of a third end-member could affect our interpretations. The analytic sensitivity $\left(0.1 \%\right.$ o for $\left.{ }^{18} \delta \mathrm{O}\right)$ versus the variability between the two end-members $-8.1 \%$ o to $-5.9 \%$ o suggests that the observed water exchange resolution is about $4.5 \%$. As Resurgence and river were monitored through time, no hypothesis was made about the end-member values for the calculation of the isotope composition of the aquifer. The observed annual and summer rainfall isotopic composition change was only used to support the model results and was not used for the calculation. The change in the river isotope signature during the flood was significant from one day to another. Short term storage, with delays of less than a day, cannot be detected. Since the exchange value obtained by isotopes does not include short term storage, the amount of exchanged water could be underestimated.

In this model, we assume an equivalent conduit diameter, which implies that the maximum discharge capacity is a constant in space. The obtained results, linking $\mathrm{Q}_{\mathrm{cm}}$ and discharge at the interface at the aquifer scale, suggest that the river fluctuations induce seasonal recharges and discharges in the conduit, creating a mixed zone in the vicinity of the conduit. If the conduit becomes narrower, $\mathrm{Q}_{\mathrm{cm}}$ will change and exchanges at the local scale can take place around this geometrical modification and create a hierarchized flow around the saturated 
conduit, increasing the influence of a hyporheic zone around the saturated conduit. Thus the karstic geometry appears to react as a hyporheic zone around the stream bed geomorphology (Cardenas et al., 2004).

\section{Conclusion:}

The comparison of the isotopic and groundwater model methods shows that exchanges take place even for steady state conditions, with a recharge and a discharge area along the karstic conduit. This spatial distribution is controlled by the maximum conduit capacity and by the discharges at the boundaries. Discharge of the conduit toward the aquifer is observed when the conduit discharge is limited by the downstream interface properties. Discharge from the aquifer to the conduit is observed when the upstream discharge at the interface is less than the conduit discharge capacity. An increasing pressure head in the conduit creates a transient local gradient around the conduit that blocks the water coming from the aquifer. When the pressure decreases, the local gradient at the interface is maximum and the observed exchanges are increased. During post flood drainage, the groundwater evolves from recently recharged water to old water coming from the local recharge area. Thus this karstic conduit appears to react as a hyporheic zone around a stream bed, implying the existence of a mixing zone.

For karst hydrology, this case-study provides field evidence of the existence of steady state exchanges that are controlled by the ratio between discharge at the boundaries governed by river water dynamics and the conduit discharge capacity governed by the conduit morphology.

The river floods control the transient storage around a karstic conduit. Consequently, the water residence times at the resurgence of the karst system are not a mix between conduit and aquifer residence times, but are a continuum between these two end-members that is controlled by the time varying water head at the boundary. The residence time distribution is not an intrinsic property of the karst system but is partly controlled by fluctuations in the river waters.

In terms of aquifer vulnerability, these residence time mixings suggest two main conclusions: (1) the vulnerability is not an intrinsic property of the aquifer as the spatial distribution of the exchanges is controlled by fluctuations in the river waters and (2) the local water located in the recharge zone of the conduit is much more vulnerable than the water located in the transport zone or in the discharge zones. Thus it could be 
appropriate to add a new zonation in vulnerability mapping that includes the spatial distribution of the recharge /transport /discharge zones of these systems.

\section{Acknowledgements:}

This work is part of the doctoral research of E. Joigneaux cofunded by the Region Centre of France and BRGM. The database used was made available by the INSU/CNRS national observatory of karstic aquifers, SNO KARST.

The groundwater model development was funded by the "Conseil Général du Loiret" through the ICERE project. 


\section{References:}

Albéric, P., 2004. River backflooding into a karst resurgence (Loiret, France). J. Hydrol. 286, 194-202. doi:10.1016/j.jhydrol.2003.09.018

Albéric, P., Lepiller, M., 1998. Oxydation de la matière organique dans un système hydrologique karstique alimenté par des pertes fluviales (Loiret, France) / Oxidation of organic matter in a karstic hydrologic unit supplied through stream sinks (Loiret, France). Water Res. 32, 20512064. doi:10.1016/S0043-1354(97)00439-9

Andreo, B., Liñán, C., Carrasco, F., Jiménez de Cisneros, C., Caballero, F., Mudry, J., 2004. Influence of rainfall quantity on the isotopic composition (18O and $2 \mathrm{H})$ of water in mountainous areas. Application for groundwater research in the Yunquera-Nieves karst aquifers (S Spain). Appl. Geochem. 19, 561-574. doi:10.1016/j.apgeochem.2003.08.002

Auterives, C., Binet, S., Albéric, P., 2014. Inferred Conduit Network Geometry from Geological Evidences and Water-Head in a Fluvio-Karstic System (Val D’Orleans, France), in: Mudry, J., Zwahlen, F., Bertrand, C., LaMoreaux, J.W. (Eds.), H2Karst Research in Limestone Hydrogeology, Environmental Earth Sciences. Springer International Publishing, pp. 49-58.

Bailly-Comte, V., Martin, J.B., Jourde, H., Screaton, E.J., Pistre, S., Langston, A., 2010. Water exchange and pressure transfer between conduits and matrix and their influence on hydrodynamics of two karst aquifers with sinking streams. J. Hydrol. 386, 55-66. doi:10.1016/j.jhydrol.2010.03.005

Binet, S., Mudry, J., Bertrand, C., Guglielmi, Y., Cova, R., 2006. Estimation of quantitative descriptors of northeastern Mediterranean karst behavior: multiparametric study and local validation of the Siou-Blanc massif (Toulon, France). Hydrogeol. J. 14, 1107-1121.

Butscher, C., Huggenberger, P., 2008. Intrinsic vulnerability assessment in karst areas: A numerical modeling approach. Water Resour. Res. 44. doi:doi:10.1029/2007WR006277

Cardenas, M.B., Wilson, J.L., Haggerty, R., 2008. Residence time of bedform-driven hyporheic exchange. Adv. Water Resour. 31, 1382-1386. doi:10.1016/j.advwatres.2008.07.006 
Cardenas, M.B., Wilson, J.L., Zlotnik, V.A., 2004. Impact of heterogeneity, bed forms, and stream curvature on subchannel hyporheic exchange. Water Resour. Res. 40, W08307. doi:doi:10.1029/2004WR003008

Charmoille, A., Binet, S., Bertrand, C., Guglielmi, Y., Mudry, J., 2009. Hydraulic interactions between fractures and bedding planes in a carbonate aquifer studied by means of experimentally induced water-table fluctuations (Coaraze experimental site, southeastern France). Hydrogeol. J. 17, 1607-1616.

Charlier J.-B., Bertrand C., Binet S., Mudry J., and Bouillier N. (2010). Use of continuous measurements of natural fluorescence of dissolved organic matter in groundwater to characterize fast infiltration through an unstable fractured hillslope. Hydrogeology Journal (18) 1963-1969

Dedewanou, M., Binet, S., Rouet, J.L., Coquet, Y., Bruand, A., Noel, H., 2015. Groundwater Vulnerability and Risk Mapping Based on Residence Time Distributions: Spatial Analysis for the Estimation of Lumped Parameters. Water Resour. Manag. 29, 5489-5504. doi:10.1007/s11269-015-1130-8

Desprez, N., 1976. Etude hydrogéologique Val d'Orléans, à l'est d'Orléans (No. BRGM 76 SGN 109 BDP). BRGM, Orléans.

Desprez, N., 1967. Inventaire et Etude hydrogéologique du Val d'Orléans (No. BRGM DSGR.67.A21). BRGM, Orléans.

Diersch, H.-J.., 2014. FEFLOW Finite Element Modeling of Flow, Mass and Heat Transport in Porous and Fractured Media. Springer Berlin Heidelberg.

Doctor, D., Alexander, E.C., Jr, Petrič, M., Kogovšek, J., Urbanc, J., Lojen, S., Stichler, W., 2006. Quantification of karst aquifer discharge components during storm events through endmember mixing analysis using natural chemistry and stable isotopes as tracers. Hydrogeol. J. 14, 1171-1191. doi:10.1007/s10040-006-0031-6 
Grasso, D.A., Jeannin, P.-Y., Zwahlen, F., 2003. A deterministic approach to the coupled analysis of karst springs' hydrographs and chemographs. J. Hydrol. 271, 65-76. doi:10.1016/S00221694(02)00321-9

Grosbois, C., Négrel, P., Fouillac, C., Grimaud, D., 2000. Dissolved load of the Loire River: chemical and isotopic characterization. Chem. Geol. 170, 179-201. doi:10.1016/S0009-2541(99)00247

Gutierrez, A., Binet, S., 2010. La Loire souterraine: circulations karstiques dans le Val d’Orléans. Geosciences.

Gooseff, M.N., McKnight, D.M., Runkel, R.L., Vaughn, B.H., 2003. Determining long time-scale hyporheic zone flow paths in Antarctic streams. Hydrol. Process. 17, 1691-1710. doi:10.1002/hyp.1210

Hartmann, A., Wagener, T., Rimmer, A., Lange, J., Brielmann, H., Weiler, M., 2013. Testing the realism of model structures to identify karst system processes using water quality and quantity signatures. Water Resour. Res. 49, 3345-3358. doi:doi:10.1002/wrcr.20229Jeannin, P.-Y., 2001. Modeling flow in phreatic and epiphreatic Karst conduits in the Höloch Cave (Muotatal, Switzerland). Water Resour. Res. 37, 191-200. doi:10.1029/2000WR900257

Joigneaux, E., Albéric, P., Pauwels, H., Pagé, H., Terray, C., Bruand, A., 2011. Impact of climate change on groundwater point discharge: backflooding of karstic springs (Loiret, France). Hydrol. Earth Syst. Sci. 2459-2470.

Joodi, A.S., Sizaret, S., Binet, S., Bruand, A., Alberic, P., Lepiller, M., 2010. Development of a DarcyBrinkman model to simulate water flow and tracer transport in a heterogeneous karstic aquifer (Val d’Orléans, France). Hydrogeol. J. 18, 295-309. doi:10.1007/s10040-009-0536-x

Jourde, H., Roesch, A., Guinot, V., Bailly-Comte, V., 2007. Dynamics and contribution of karst groundwater to surface flow during Mediterranean flood. Environ. Geol. 51, 725-730. doi:10.1007/s00254-006-0386-y 
Kovács, A., Perrochet, P., Király, L., Jeannin, P.-Y., 2005. A quantitative method for the characterisation of karst aquifers based on spring hydrograph analysis. J. Hydrol. 303, 152164. doi:10.1016/j.jhydrol.2004.08.023

Lalot, E., Curie, F., Wawrzyniak, V., Baratelli, F., Schomburgk, S., Flipo, N., Piegay, H., Moatar, F., 2015. Quantification of the contribution of the Beauce groundwater aquifer to the discharge of the Loire River using thermal infrared satellite imaging. Hydrol Earth Syst Sci 19, 4479-4492. doi:10.5194/hess-19-4479-2015

Le Borgne, F., Treuil, M., Joron, J.L., Lepiller, M., 2005. Méthode de sondage géochmique des aquifères à l'aide des lanthanides naturels et de leurs complexes EDTA : Cas des aquifères alluvial et karstique du Val d’Orléans. Bull. Société Géologique Fr. 176, 513-529.

Le Borgne, F., Treuil, M., Joron, J.L., Lepiller, M., 2006. Bilan des impacts hydrogéochimiques naturels et anthropiques à l’intérieur du réseau karstique du Val d’Orléans établi à l'aide des éléments majeurs : Confirmation et tentative de quantification du modèle de « confinement dynamique ». Bull. Société Géologique Fr. 177, 37-50.

Lee, E.S., Krothe, N.C., 2001. A four-component mixing model for water in a karst terrain in southcentral Indiana, USA. Using solute concentration and stable isotopes as tracers. Hydrochem. Springs 179, 129-143. doi:10.1016/S0009-2541(01)00319-9

Lepiller, M., 2006. Val d’Orléans, in: Roux, J.C. (Ed.), Aquifères et Eaux Souterraines En France. pp. $200-214$.

Long, A.J., Putnam, L.D., 2004. Linear model describing three components of flow in karst aquifers using 180 data. J. Hydrol. 296, 254-270. doi:10.1016/j.jhydrol.2004.03.023

Marfia, A.M., Krishnamurthy, R.V., Atekwana, E.A., Panton, W.F., 2004. Isotopic and geochemical evolution of ground and surface waters in a karst dominated geological setting: a case study from Belize, Central America. Appl. Geochem. 19, 937-946. doi:10.1016/j.apgeochem.2003.10.013 
Martin, J.C., Amraoui, N., Pathirana, N., 2003. Caractérisation du risque d'inondation par remontée de nappe sur le val d’Orléans (No. BRGM/RP-52121-FR).

Mengis, M., Schif, S.., Harris, M., English, M.., Aravena, R., Elgood, R., MAclean, A., 1999. Multiple Geochemical and Isotopic Approaches for Assessing Ground Water NO3- Elimination in a Riparian Zone. Ground Water 37, 448-457. doi:10.1111/j.1745-6584.1999.tb01124.x

Millot, R., Petelet-Giraud, E., Gurerrot, C., Negrel, P., 2010. Multi-isotopic composition ( $\delta 7 \mathrm{Li}-\delta 11 B-$ SD-180) 601 of rainwaters in France: Origin and spatio-temporal characterization. Applied Geochemistry 25, 1510-1524.

Négrel, P., Petelet-Giraud, E., Barbier, J., Gautier, E., 2003. Surface water-groundwater interactions in an alluvial plain: Chemical and isotopic systematics. J. Hydrol. 277, 248-267. doi:10.1016/S0022-1694(03)00125-2

Perrin, J., Jeannin, P.-Y., Zwahlen, F., 2003. Epikarst storage in a karst aquifer: a conceptual model based on isotopic data, Milandre test site, Switzerland. J. Hydrol. 279, 106-124. doi:10.1016/S0022-1694(03)00171-9

Peterson, E.W., Wicks, C.M., 2006. Assessing the importance of conduit geometry and physical parameters in karst systems using the storm water management model (SWMM). J. Hydrol. 329, 294-305. doi:10.1016/j.jhydrol.2006.02.017

Pianosi, F., Beven, K., Freer, J., Hall, J.W., Rougier, J., Stephenson, D.B., Wagener, T., 2016. Sensitivity analysis of environmental models: A systematic review with practical workflow. Environ. Model. Softw. 79, 214-232. doi:10.1016/j.envsoft.2016.02.008

Razavi, S., Gupta, H.V., 2015. What do we mean by sensitivity analysis? The need for comprehensive characterization of "global" sensitivity in Earth and Environmental systems models. Water Resour. Res. 51, 3070-3092. doi:doi:10.1002/2014WR016527

Reimann, T., Rehrl, C., Shoemaker, W.B., Geyer, T., Birk, S., 2011. The significance of turbulent flow representation in single-continuum models. Water Resour. Res. 47, W09503. doi:10.1029/2010WR010133 
Shewchuk, J., 1996. Triangle: Engineering a 2D quality mesh generator and Delaunay triangulator, in: Lin, M., Manocha, D. (Eds.), Applied Computational Geometry Towards Geometric Engineering, Lecture Notes in Computer Science. Springer Berlin Heidelberg, pp. 203-222.

Sophocleous, M., 2002. Interactions between groundwater and surface water: the state of the science. Hydrogeol. J. 10, 52-67. doi:10.1007/s10040-001-0170-8

Waschkowski, E., 1973. Le calcaire de Beauce. Bull Liaison Labo P Ch spécial U, 115.

White, W.B., 1999. Geomorphology and Hydrology of Karst Terrains. Oxford University Press.

Wu Y. and Hunkeler D., 2013. Hyporheic exchange in a karst conduit and sediment system - a laboratory analog study. Journal of hydrology, 501 pp. 125-132 


\section{Figures and Table}

Figure 1: Hydrogeological setting: 0 - 1 localizes the cross section presented in section 3.2. F1, F2 and F3 are the boreholes used to characterize aquifer isotope signatures.

Figure 2: Description of the hydrodynamic model: Horizontal saturated 2D aquifer, with 45000 nodes created with increasing density around the conduit. The constant values for the hydrodynamic calculations are the length, the width, thickness, the recharge, the hydraulic conductivity, the specific storage of the aquifer, the cross sectional area and the roughness coefficient of the conduit. The interface properties (green cross) are defined by a transfer rate. The 0 and 1 boundary conditions are constant heads in the river.

Figure 3: Isotope composition in the Val de Loire: a) sampling in the Loire and the Bouillon resurgence from November 2008 to September 2009; b) Loire and Bouillon resurgence sampling from 19 August to 2 September 2008. c) Loire and Bouillon resurgence during the November 2008 flood. Colors on B and $C$ depend on the resurgence sampling date with a 3.5 days interval for the Loire river

Figure 4: $\delta 180$ and $\delta D$ evolution during the November 2008 flood at the resurgence (crosses) and at the Loire River 3.5 days previously (circles). Loire water level (blue line, right axes), observed discharge (triangles) and modeled discharge (red line left axes) at the resurgence. The calculated hygrogram separation at the resurgence (dashed line) delineates the $\% \mathrm{C}$ water from the conduit with respect to the $\%$ A water from the aquifer [-]. 
Figure 5: Calibration of the hydrodynamic model with field measurements. (a) The comparison between observed water velocity (dots) and calculated water velocity for a 10, 20 and 30 friction coefficient suggests a roughness coefficient of $13 \mathrm{~m}^{1 / 3} / \mathrm{s}$. (b) The relationship between the roughness coefficient, the discharges and the conduit cross sectional area suggests a $40 \mathrm{~m}^{2}$ equivalent conduit cross sectional area for a $10 \mathrm{~m}^{3} / \mathrm{s}$ discharge. Hydraulic conductivity (Ks) is fixed $25 \mathrm{E}-4 \mathrm{~m} / \mathrm{s}$.

Figure 6: Water head in aquifer projected on the $x$ axes. Comparison between observed (triangles) and calculated water heads in the conduit (red line) and in the aquifer (blue line with the square points). Evidence of the spatial variability of the water exchanges between the conduit and the aquifer for a porous hydraulic conductivity of $25 \mathrm{E}-4 \mathrm{~m} / \mathrm{s}$, with a recharge zone $(\% Q<1)$, a transport zone $(\% Q=1)$ and a discharge zone $(\% Q>1)$

Figure 7: Transversal cross section of the time evolution of the water heads calculated for an upstream transversal cross section $(X=5000 m)$ during a four day flood. The conduit is schematically represented by the blue circle at $x=2000 \mathrm{~m}$ (real location is $Z=80 \mathrm{~m}$ )

Figure 8: Isotope evolution during the November 2008 flood including calculated values for the aquifer. The dots, crosses and stars are respectively Loire, Resurgence and Boreholes. Colors depend on the sampling date, with a 3.5 day interval for the Loire River. Triangles are model estimations of the aquifer isotope signature, estimated with the \%A from the groundwater model.

Figure 9: Conceptual model of flow around a saturated karstic conduit fed by diffuse and allogeneic recharge, with location of the recharge, discharge, transport and hyporheic zones. 
Table 1: Values of the discharge at the upper boundary $\left(\mathrm{Q}_{\mathrm{co}}\right)$, the maximum discharge capacity (Qcm), the discharge ratio (\%Q) of the Val d'Orléans conduits for a given Loire River level at Jargeau during the 2008 November flood.

\begin{tabular}{cccc}
$\mathbf{h}_{\mathbf{0}}(\mathbf{m})$ & $\mathbf{Q}_{\mathrm{co}}\left(\mathrm{m}^{3} / \mathrm{s}\right)$ & $\mathbf{Q}_{\mathrm{cm}}\left(\mathbf{m}^{3} / \mathbf{s}\right)$ & $\% \mathbf{Q}$ \\
\hline 97.8 & 5.0 & 11.0 & 0.45 \\
98.4 & 11.0 & 12.5 & 0.88 \\
99.1 & 13.5 & 14.5 & 0.93 \\
101.6 & 20.0 & 20.0 & 1.00
\end{tabular}

Table 2: Sensitivity analysis of the groundwater flow model. Estimation of the amount of water flowing from the surrounding aquifer (\%A) for models where the $X$ value (the value of the parameters chosen for the best fit model) deviates about + or $-\sigma$. The sensitivity of the $\% A$ value $(\Delta \% A)$ is given for a $2 \sigma$ variability.

\begin{tabular}{|lccc|ccc|}
\hline & & & & \%A if parameter values are: \\
\hline Parameter & units & $\mathbf{x}$ & $\sigma$ & $\mathbf{x}+\sigma$ & $\mathbf{x}-\boldsymbol{\sigma}$ & $\Delta \% \mathrm{~A}$ \\
\hline $\mathrm{Q}_{\mathrm{CO}}$ & $\mathrm{m}^{3} / \mathrm{s}$ & 11 & 5.5 & 0.09 & 0.74 & 64.8 \\
$\mathrm{Q}_{\mathrm{c}}$ & $\mathrm{m}^{3} / \mathrm{s}$ & 14 & 7 & 0.17 & 0.17 & 0.8 \\
$\mathrm{Q}_{\mathrm{C} 1}$ & $\mathrm{~m}^{3} / \mathrm{s}$ & 12.4 & 6.2 & 0.16 & 0.16 & 0.0 \\
Recharge & $\log (\mathrm{m} / \mathrm{s})$ & -10.8 & 1 & 0.17 & 0.17 & 0.0 \\
$i$ & $/$ & $5.0 \mathrm{E}-04$ & $2.5 \mathrm{E}-04$ & 0.19 & 0.16 & -2.2 \\
$\mathrm{Q}_{\mathrm{A} 1}$ & $\mathrm{~m}^{3} / \mathrm{s}$ & 2.6 & 0.5 & 0.28 & 0.15 & -12.7 \\
$\mathrm{Ks}$ & $\log (\mathrm{m} / \mathrm{s})$ & -2.6 & 1 & 0.25 & 0.14 & -12.0 \\
$\mathrm{Q}_{\mathrm{A} 0}$ & $\mathrm{~m}^{3} / \mathrm{s}$ & 1.5 & 0.5 & 0.66 & 0.10 & -56.4 \\
\hline
\end{tabular}




\section{Figure 1}

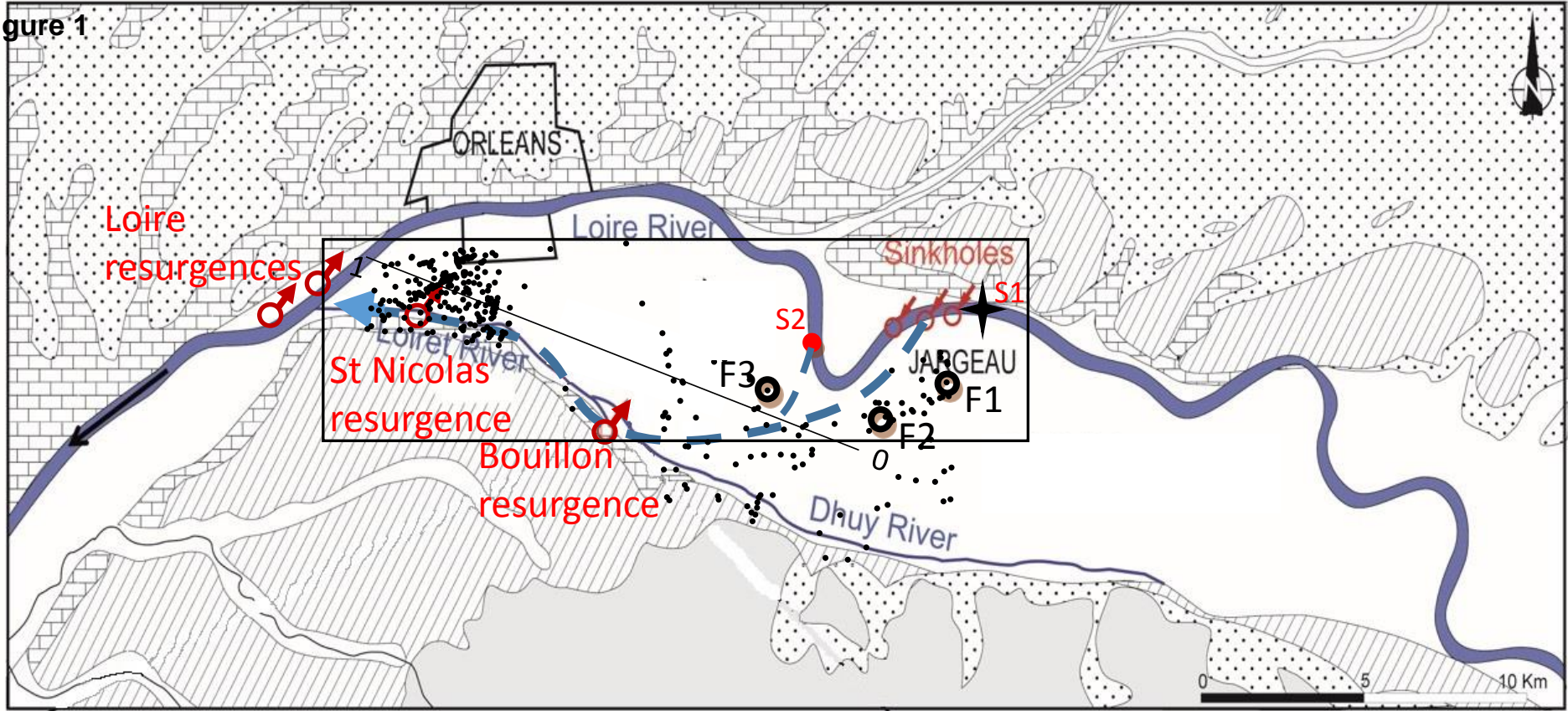

$\square$ Modern and würm alluvium

Rin Riss alluvium

$\square$ Mindel alluvium

$\therefore$ Sologne sand and clay, Burdigalian

$\square$ Beauce limestone outcrop, Aquitanian

of Most known sinking stream area

of B : Bouillon resurgence, spring of the river Loiret
- Borehole for aquifer sampling

- Borehole in the conduit

- Borehole for water-head measurements

+ Water level measurements in the River

Groundwater flow direction

$1-0$ Cross section presented in Figure 4

Model boundary

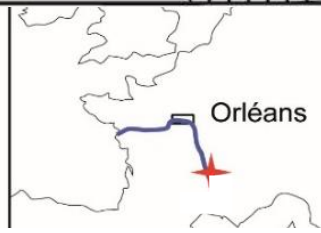

$3_{2}$

(modified from Albéric, 2004) 
Figure 2

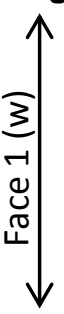

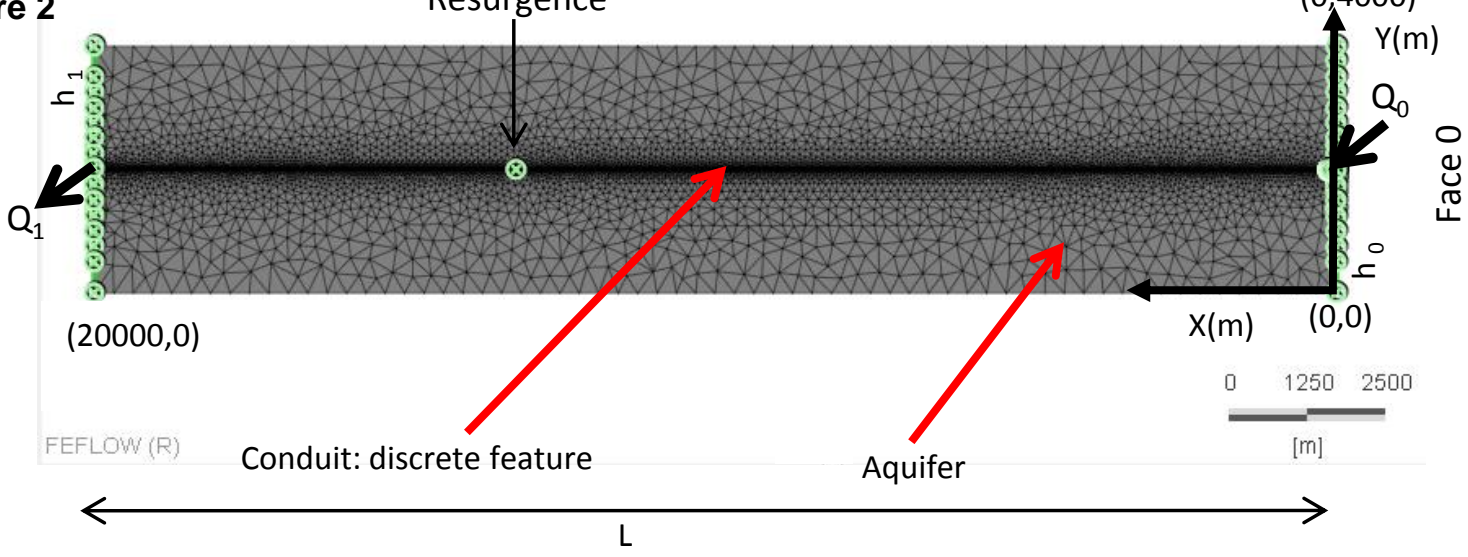




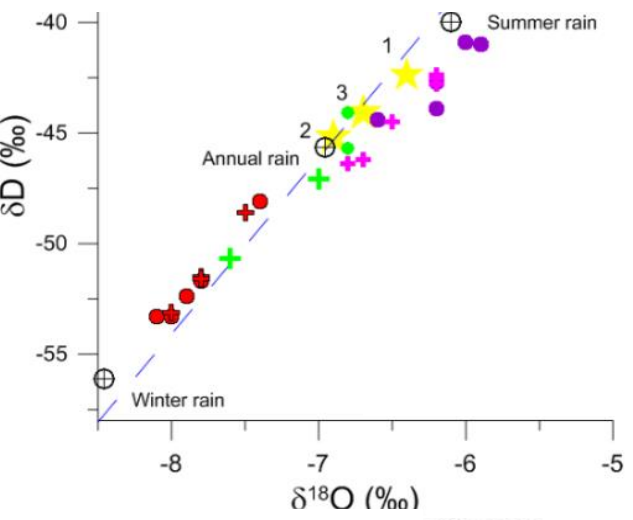

C/November 2008

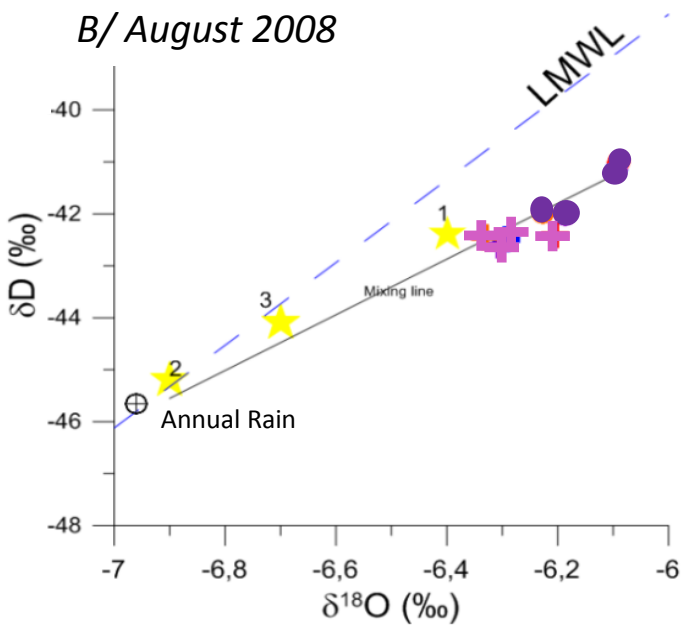
flood

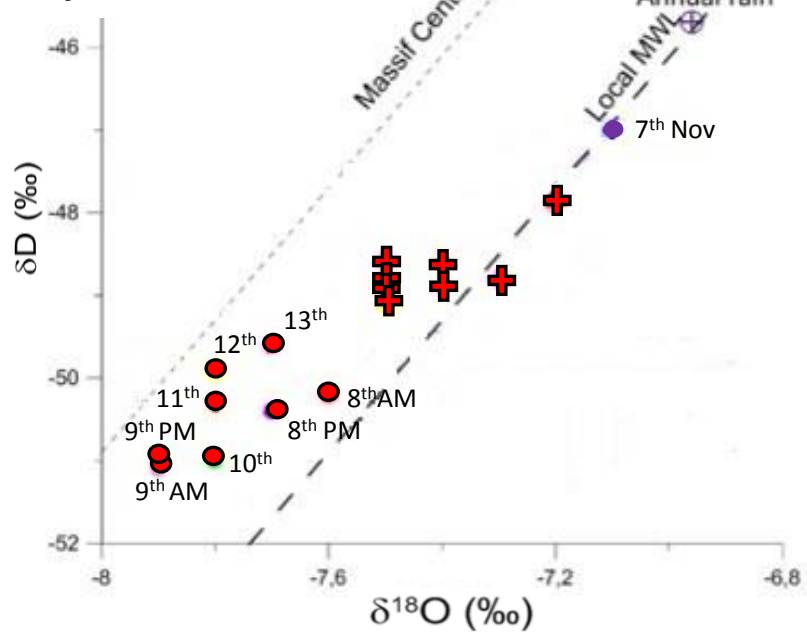

\section{Legend:}

Aquifer - Boreholes

River-high flow

River - low flow

Resurgence - high flow

Resurgence - low flow

River - May 2008

Resurgence - May 2008

Rain 

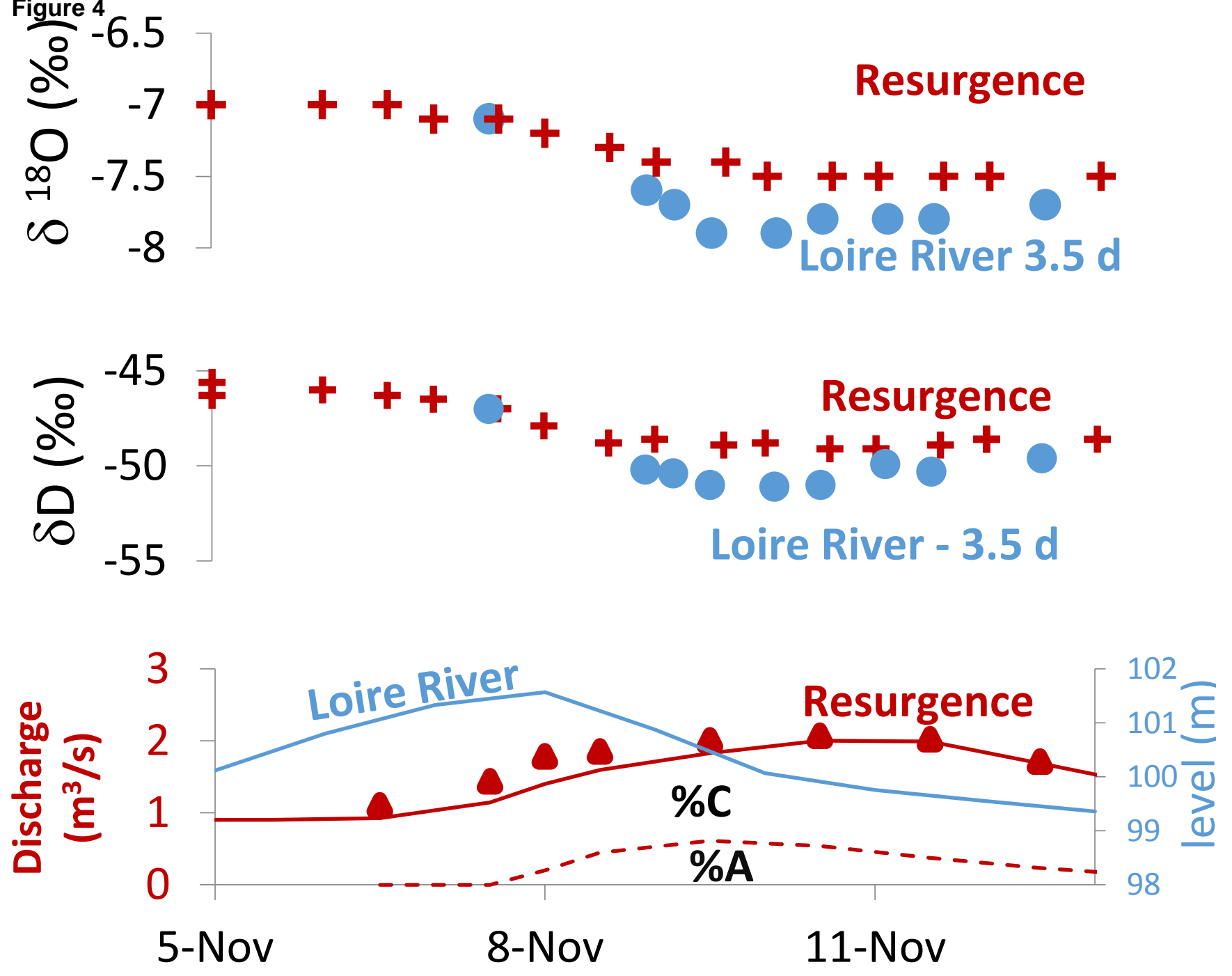


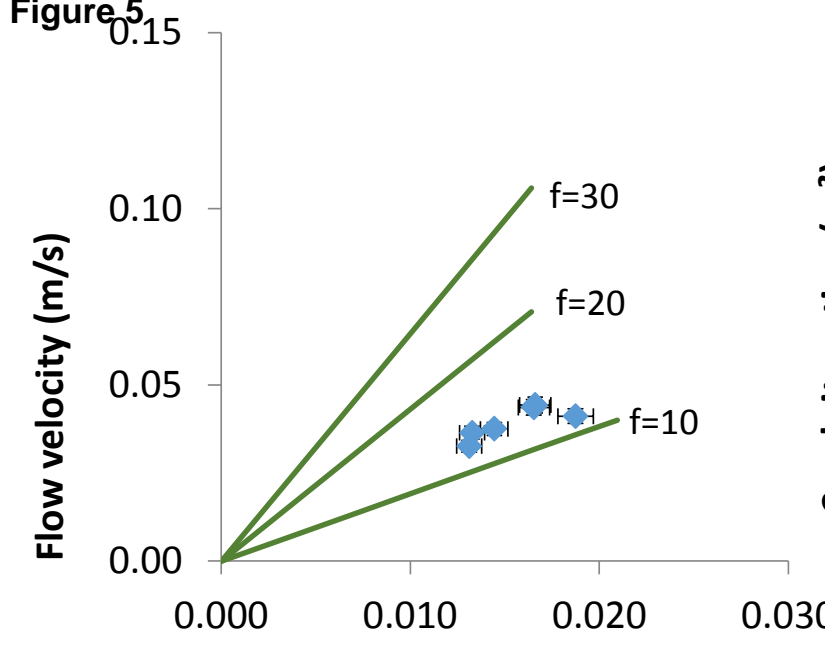

Hydraulic gradient $\mathrm{V}(\mathrm{Dh} / \mathrm{L})$

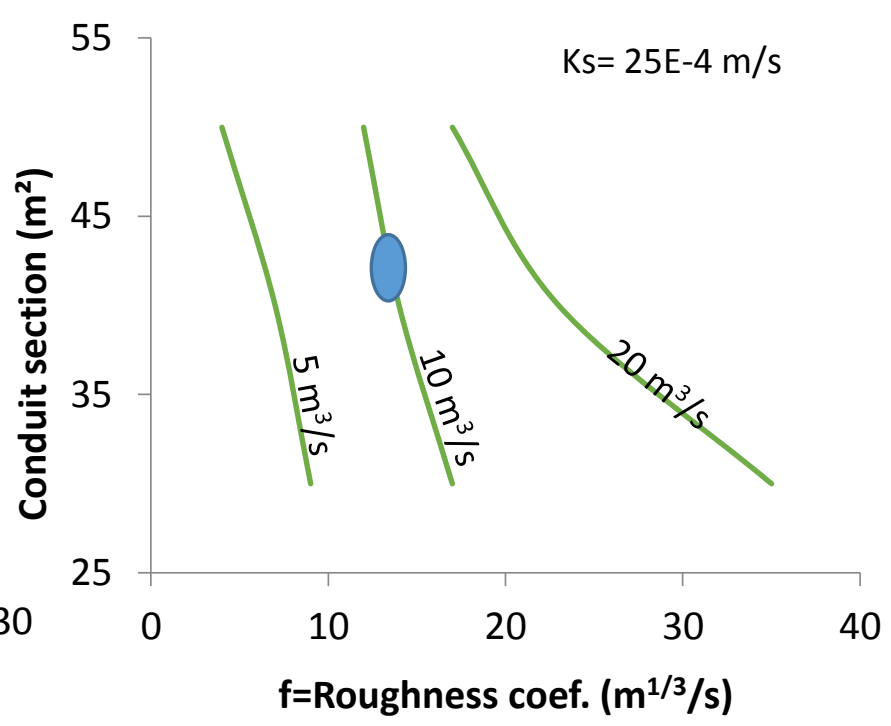




\section{Figure 6}

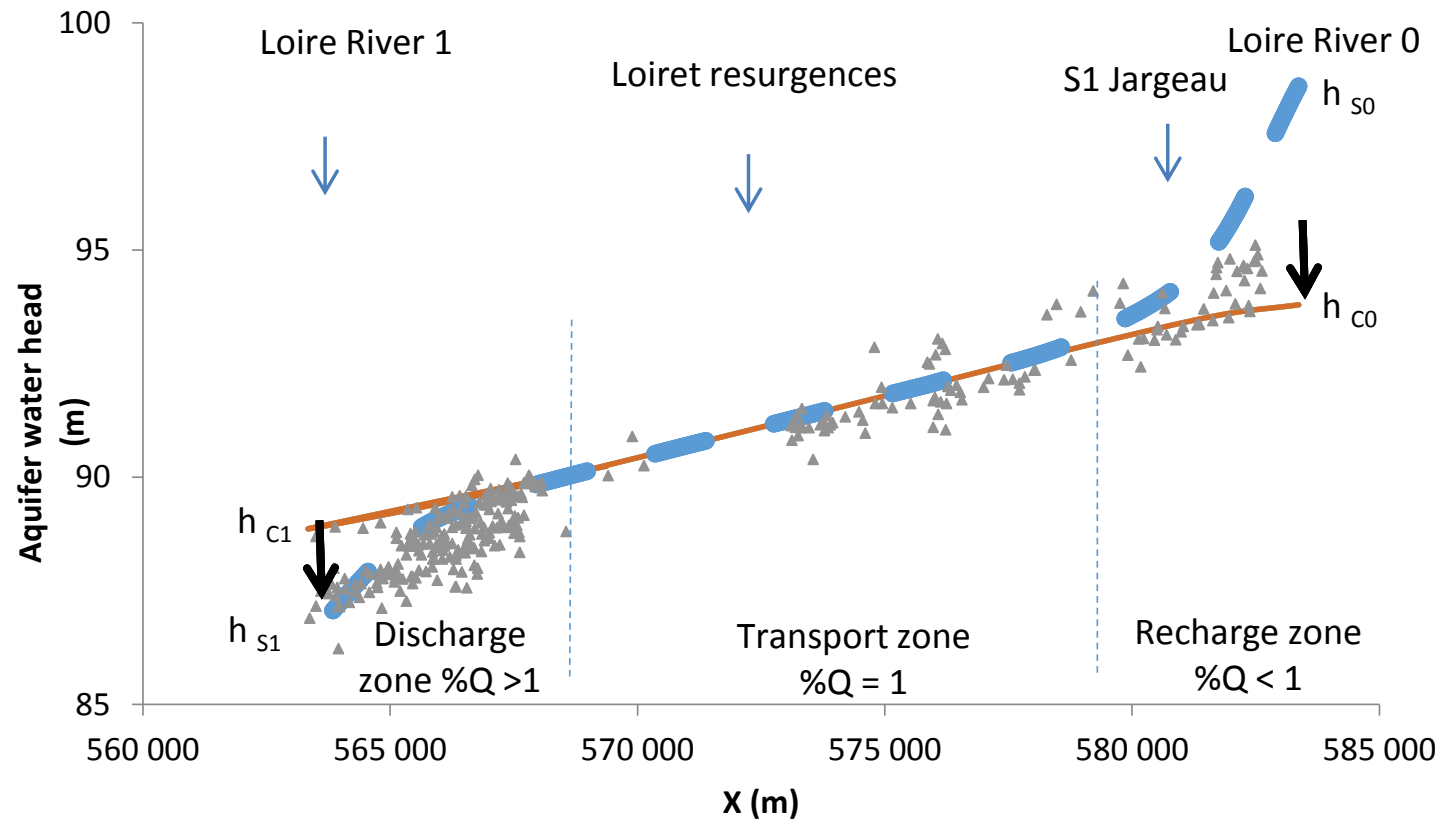


Figure 7

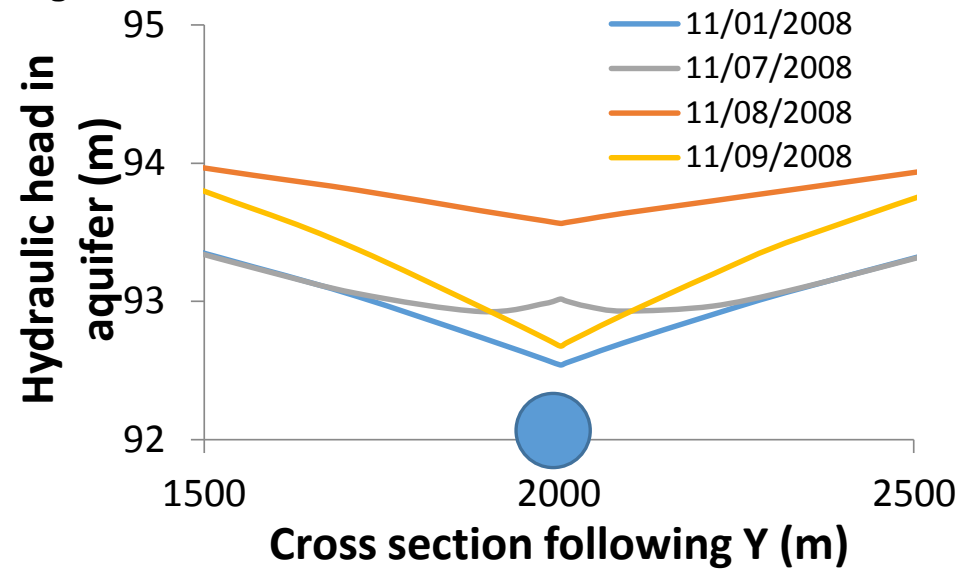




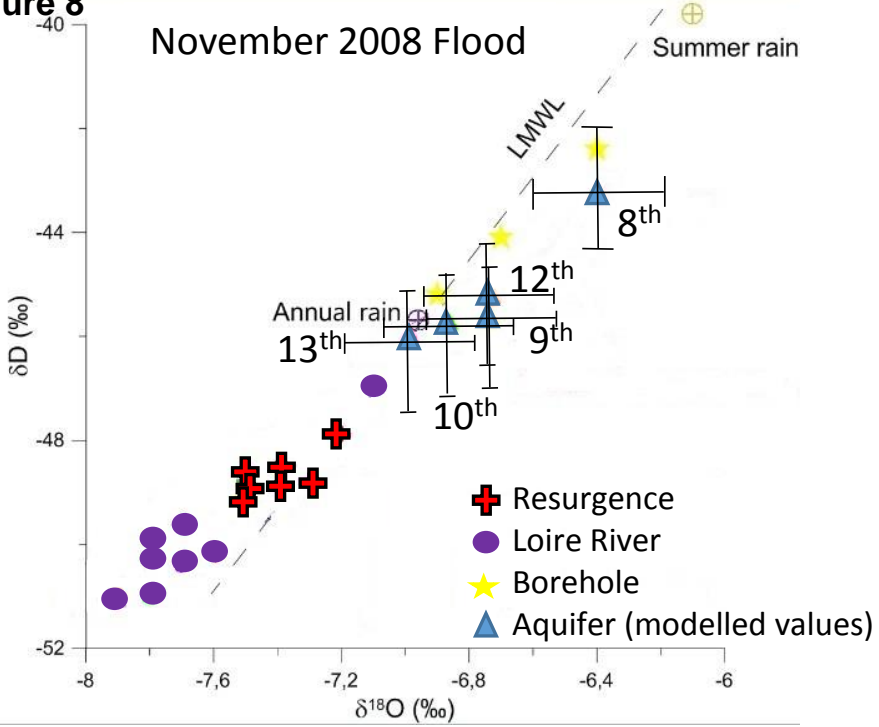


$\longleftarrow$ Allogenic recharge $\longrightarrow$

Autogenic recharge

Resurgence

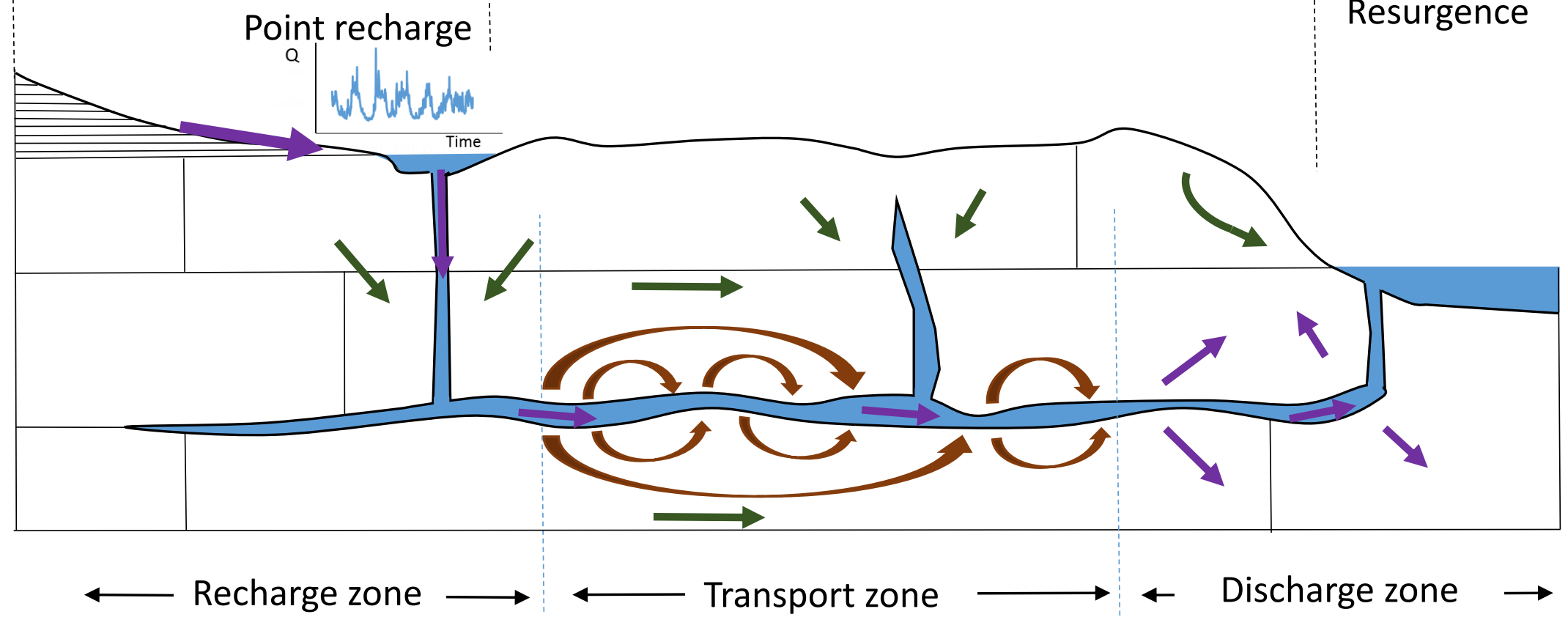

Legend:

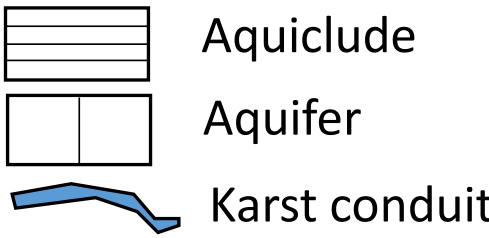

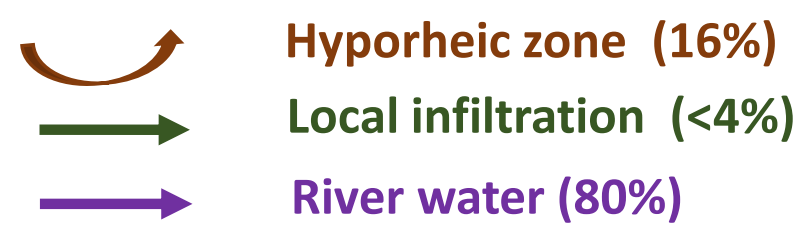

Hyporheic zone (16\%)

River water (80\%) 


\section{Highlights:}

Water exchanges between karstic conduit and aquifer are driven by pressure gradient Isotopic signature determination and water head measurements were conducted on a karstic aquifer

Exchanges from aquifer water to conduit take place even in pseudo-steady state conditions

The model evidences steady-state exchanges evolving from recharge to discharge areas

With floods, these exchanges fluctuate around the equilibrium and create an underground hyporheic zone 